\title{
A Comparison of Contemplative vs. Transformative Instruction in EFL Learners' Oral Performance: A Mixed-Methods Study
}

\section{Sahar Ahmadpour}

Department of English Language, Bonab Branch, Islamic Azad University, Bonab Iran Hassan Asadollahfam ( $\sim$ Asadollahfam@gmail.com )

Islamic Azad University Bonab Branch https://orcid.org/0000-0003-1643-3372

Davud Kuhi

Department of English Language, Maragheh Branch, Islamic Azad University, Maragheh Iran

\section{Original article}

Keywords: speaking, contemplative teaching, transformative teaching, attitude, English as a foreign language

Posted Date: September 30th, 2020

DOl: https://doi.org/10.21203/rs.3.rs-80913/v1

License: (a) (1) This work is licensed under a Creative Commons Attribution 4.0 International License. Read Full License 


\section{Abstract}

The present study aimed at comparing the effectiveness of contemplative and transformative teaching approaches in the teaching of second language speaking skill. These two approaches move away from the traditional instructional approaches by making the learners in center of teaching-albeit in different ways. For this purpose, a total of 41 English as a foreign language (EFL) learners were exposed to each pedagogical approach and their speaking development was measured prior to and following the relevant practices. Furthermore, participants were interviewed to glean out richer insights about the efficacy of each approach. Results of both statistical analyses and interview analyses indicated the superiority of the transformative approach in bringing about speaking enhancement in learners' posttest scores. However, the contemplative approach was not found to be effective. These findings offer significant implications for teachers and teacher trainers regarding oral language development which are further discussed.

\section{Introduction}

Speaking is a fundamentally complex and multifaceted skill, the specialized utilization of which demands sufficient knowledge of linguistic resources such as grammatical knowledge, vocabulary and pronunciation, knowledge of pragmatic norms, knowledge of cultural rules of discourse, ability to manage the conversation, or the ability to deal with the difficulties in interaction by making use of numerous communication strategies (McDonough \& Mackey, 2013). Even more complicated is that these knowledge types all need to be used in real time, normally in seconds, in contexts when the attentional resources limited since they should be simultaneously devoted to both the communicative goal, opting for the crucial linguistic resources and producing the real meanings, as well as monitoring all the stages of this process, appraising the context in which interaction takes place, using the subject knowledge, planning the content of language, and simply listening to the interlocutor (Khezrlou, 2020a; Oliver \& Philp, 2014).

Obviously, for effective communication to occur, it is of utmost importance that all of these take place involuntarily meaning that speakers should elicit their implicit rather than explicit knowledge of second language (L2) (Oliver \& Philp, 2014). This therefore poses a challenge to L2 learners, not only due to insufficiencies in communicative competence, but also because they need to use compensatory strategies (Segalowitz, 2010). According to these difficulties, then, it is a very difficult ask to acquire communicative competence in the language classroom which has a balanced attention to fluency and accuracy, making learners ready for the unsettled contexts in which they will have to communicate (Khezrlou, 2020b, 2019a, 2019b; Khezrlou \& Sadeghi, 2012). Thus, it is important to investigate the suitability of different instructional practices regarding speaking development particularly in English as a foreign language (EFL) contexts where learners have limited exposure to the target language. As teaching methods move from traditional to more communicative ones, the need for different theories and approaches to language teaching is felt more than ever. The present study was an attempt to figure out 
how effective the transformative and contemplative approaches were in developing EFL learners' speaking performances along with identifying their strength and weaknesses.

\section{Second Language Speaking Development}

Speaking is a combinatorial skill which consists of performing different activities concurrently (Johnson, 1996). Goh and Burns (2012) delineate speaking as a greatly complicated and active skill that encompasses the use of multiple concurrent processes such as cognitive, physical and socio-cultural capabilities and a speaker's information and abilities have to be activated quickly in real-time. Speaking is considered a productive skill which therefore entails reacting to the incoming information without any time drift. The speakers are required to sustain the stream of the speech and should accomplish a degree of fluency and automaticity in both planning and the generation of language (Sydorenko, Smits, Evanini, \& Ramanarayanan, 2019; Thornbury, 2005). With regard to the instruction of the speaking skill, it is worthwhile for teachers to comprehend what speaking competence entails and the reasons behind its complex nature since it needs beyond the speaking activities in the classroom (Goh \& Burns, 2012). Second language speaking proficiency encompasses knowledge of language and discourse, basic speaking capabilities, and interaction and discourse strategies (Goh \& Burns, 2012). The following model (Fig. 1) explicates this integration with more details.

Learning to speak in a second language includes promoting the capability of employing these elements, empowering the learners to generate unplanned, impulsive, automatic, proper, and correct oral language. This ability can be fostered only through its use and it also necessitates learners to be conscious of their own language learning processes. Therefore, it is commonly accepted that teachers need to advance learner autonomy which is considered as an essential dimensions of EFL/ESL instruction. In other words, learner autonomy is the capacity to be responsible for one's own learning (Little, 1991). It is also defined as "a capacity and willingness to act independently and in cooperation with others, as a social, responsible person" (Dam et al., 1990, p. 102). The classroom needs to afford an appropriate learning atmosphere through the setting up of the discourse of learner autonomy by the teacher (Little, 2003). In this type of a class, learners are motivated to select, use the target language and evaluate their products (Khezrlou, 2012a, 2012b; Khezrlou, Ellis \& Sadeghi, 2017). Learners' intrinsic motivation is involved intentionally by making use of their interest in autonomy, and at the same time cultivating connection, and urging competence. The objective is consistently to empower them to generate and use the target language (in this study English) through impromptu and authentic activities. Such a learning context would then enable and permit the learners to advance a variety of second language discourse and maintains their focus on task and enhances their motivation (Little, 2003).

\section{Contemplative and Transformative Teaching Approaches}

Second language acquisition (SLA) researchers have been consistently looking into finding effective approaches to the second language speaking development. One of the approaches which is ignored in 
many EFL context, namely Iran, is contemplative approach which is "an educational philosophy that infuses learning with experiences of compassion, awareness, and insight through practice of contemplative disciplines" (Gyeltshen, 2016, p. 89).

Zajonc (2009) states that the goal of contemplative approach is to join insight, compassion, wisdom, and love in a meaningful way to one's life, and to meet these goals we must "learn to be ever more awake. Another approach which is used in Western EFL/ESL countries in the last decades is the transformative approach which means teaching to make a difference. In transformative teaching, the teacher tries to grow students' intentions, creative actions and purposeful engagement in identity formation (Marshall, Sears, Louise, Roberts, \& Schubert, 2007). Fisher-Yoshida, Geller, and Schapiro (2009) define transformation as "an outcome refers to a deep and lasting change ... a developmental shift or a change in worldview. .. enabling people to move toward habits of mind and habits of being" (p. 7).

D'Amato and Krasny (2011) believe that transformative learning occurs when a learner has to reinterpret current experiences since previous assumptions are not relevant anymore, and new constructs are needed for the cognitive system in order to make the novel and confusing perceptions intelligible. Therefore, this approach provides the learner with new perspectives and includes "insight into the source, structure, and history of a frame of reference, as well as judging its relevance, appropriateness, and consequences" (Mezirow, 1997, p. 61).

A large number of studies have been carried out on transformative and contemplative teaching in Western countries (Baumgatner, 2012; Bush, 2006; Byrnes, 2009; Zajonc, 2009), but there is little evidence about the practical researches on these approaches in Iran. There is no doubt we will avail from such approaches in developing both receptive and productive language skills. In this study, the inquirer used these approaches to find out how they can improve the speaking skills of Iranian EFL learners.

Byrnes (2012) carried out a research to figure out how a contemplative orientation to teaching facilitates wholeness in ESL students. In her study, she considered three main features of contemplative teaching, that is, compassion, integrity, and mindfulness. These features influence the roles of teachers and students in the classroom in a way that they should begin with not only mind and head but also heart and body. Peter Nitschke and Peter Malvinci (2013) have also conducted a research on this topic in Manlia, Philippines which focused on the process of transformative learning. In their study, participants experienced a new type of learning. The researchers concluded that critical thinking is basically built up on the pillars of meaningful learning which by nature arises from transformative theory. According to Castro, Perinan and Bueno (2008), transformative learning is expected to lead the students towards reframing their learning and discussing their observations about learning needs to reconstruct the pedagogy of ESL and EFL.

\section{Perceptions}


Suitability of any teaching approach would be doubted without considering the learners' attitudes and perceptions (Biggs, 1992; Khezrlou, 2019c). Studies on learners' beliefs about knowledge (Belenky et al., 1986) have indicated a developmental pattern that grows from a simplistic view of knowledge as unconditional and forced by authorities, to a more sophisticated understanding of the complexities of different knowledge claims, and the need to come up with personal interpretations based on evidence and analytic reasoning. The study by Marton et al. (1993) revealed a developmental sequence in which six qualitatively different understandings of learning, broadly categorized into quantitative/reproductive and qualitative/constructivist dimensions, were attributed to opinions about knowledge and influenced learners' orientations to learning and teaching (Biggs, 1989). Quantitative attitudes towards learning have a corresponding viewpoint of knowledge as absolute and as inclusive of a detached body of correct opinions and facts. As a result, learning is regarded as an accumulation of individual pieces of knowledge, most effectively obtained by surface strategies such as rote learning which are meant for reproducing 'the facts' (Perry, 1981).

Qualitative or constructivist attitudes to knowledge and learning are connected to the relationship between different ideas, and the evaluation of substitutive perspectives. This awareness is likely to lead to deeper approaches to learning in which one deals with the complexity of the material and creating individual meaning. The relationship between attitudes towards learning, approaches to teaching and learning results is not, nevertheless, necessarily simple. Entwistle et al. (1991) explain the apparent and undoubtable incongruence in the relationship between attitudes and approaches to pedagogy, and the learning context, since the literature suggests both that attitudes and approaches are firm but they can be influenced by the learning context.

Biggs $(1989,1992)$ has maintained an interactive systems model of teaching and learning to monitor the ways learners' common attitudes to and approaches to learning are linked to specificities in the learning context to bring about particular learning results. The system consists of three components: presage, process, and product. Presage includes both the learner characteristics with regard to beliefs about knowledge and views of teaching, and also the learning context, including teacher and school characteristics. Process components comprise learners' views of a specific learning context and the particular learning strategies that they accordingly select for that learning activity. The product, or learning outcome, is mostly influenced by the strategy selected. In the present study, the learning outcome in terms of speaking development was investigated based on learners' opinions about the two teaching approaches.

\section{Method}

In light of the abovementioned gaps in the literature, the present study sought to address the following research questions:

RQ1: Does contemplative teaching approach have any significant effect on EFL learners speaking performance? 
RQ2: Does transformative teaching approach have any significant effect on EFL learners speaking performance?

RQ3. What are EFL learners' attitudes towards the use of contemplative teaching approach in speaking classes?

RQ4. What are EFL learners' attitudes towards the use of transformative teaching approach in speaking classes?

\section{Participants}

The population for this study is defined as all intermediate adult learners who study English in a private language school in Boukan, during the sampling time frame. A total of 41 English as a foreign language (EFL) participants were selected out of a language school in Boukan based on purposeful and convenient sampling techniques because of the availability principle. Participants included both male $(\mathrm{N}=17)$ and female $(N=24)$ learners. Participants' level of proficiency was intermediate based the courses they had passed in the institute and the placement test of the institute. However, in order to ensure the homogeneity of participants, the Preliminary English Test (PET) was administered. Two intact classes were used in this study, with each being assigned to one treatment condition. Class $A(N=21)$ received contemplative transformative learning program and Class $B(N=20)$ was exposed to transformative teaching and learning. Regarding the age factor, students fell within the age range of $20-25$. Participants were for the middle-class socioeconomic background. Their first language was Kurdish, yet they were also familiar with Farsi as the official language of Iran. All participants were informed of the purpose of this study through oral consents and agreed to take part in the experiment.

\section{Pre- test}

In order to be aware of learners' speaking performance, speaking section of a new version of PET test was utilized. The participants' responses to the speaking test were measured according to the score band list and these scores were considered as the pre-test scores of the EFL learners. It needs to be noted that in both the pretest and posttest of the PET used in this study, three parts were included:

Speaking part 1: short questions and answers between the learner and the researcher

Speaking part 2: looking at a visual and discussing it with the other candidate

Speaking part 3: having a 'long turn' to speak about a photograph for one minute

The Speaking section is worth $25 \%$ of the total score for the exam. Assessment Scales are divided into six bands from 0 to 5 , with 0 being the lowest and 5 the highest. Descriptors for each criterion are provided for bands 1, 3 and 5 and indicate what a candidate is expected to demonstrate at each band. The assessor awards marks for three individual criteria: Grammar and Vocabulary, Pronunciation and Interactive Communication. Details of scoring are presented in Table 1. 
Table 1. Assessment Scale for the Speaking Part of PET

\begin{tabular}{|c|c|c|c|}
\hline A2 & Grammar and Vocabulary & Pronunciation & Interactive Communication \\
\hline 5 & $\begin{array}{l}\text { - Shows a good degree of } \\
\text { control of simple } \\
\text { grammatical forms. } \\
\text { Uses a range of appropriate } \\
\text { vocabulary when talking } \\
\text { about everyday situations. }\end{array}$ & $\begin{array}{l}\text { - Is mostly intelligible, and has } \\
\text { some control of phonological } \\
\text { features at both utterance } \\
\text { and word levels. }\end{array}$ & $\begin{array}{l}\text { - Maintains simple exchanges. } \\
\text { - Requires very little prompting } \\
\text { and support. }\end{array}$ \\
\hline 4 & \multicolumn{3}{|c|}{ Performance shares foanres of Bands 3 and 5.} \\
\hline 3 & $\begin{array}{l}\text { - Shows sufficient control of } \\
\text { simple grammatical forms. } \\
\text { - Uses appropriate vocabulary } \\
\text { to talk about everyday } \\
\text { siltuations. }\end{array}$ & $\begin{array}{l}\text { - Is mostly intelligible, despite } \\
\text { limited control of phonological } \\
\text { features. }\end{array}$ & $\begin{array}{l}\text { - Maintains simple exchanges, } \\
\text { despite some difficully. } \\
\text { - Requires prompting and } \\
\text { support. }\end{array}$ \\
\hline 2 & \multicolumn{3}{|c|}{ Performance shares feanures of Bands 1 and 3 . } \\
\hline 1 & $\begin{array}{l}\text { - Shows only limited control of } \\
\text { a few grammatical forms. } \\
\text { - Uses a vocabulary of } \\
\text { isolated words and phrases. }\end{array}$ & $\begin{array}{l}\text { - Has very limited control of } \\
\text { phonological features and is } \\
\text { offen unintelligible. }\end{array}$ & $\begin{array}{l}\text { - Has considerable difficulty } \\
\text { maintaining simple exchanges. } \\
\text { - Requires additional prompting } \\
\text { and support. }\end{array}$ \\
\hline 0 & \multicolumn{3}{|c|}{ Pefformance below Band 1 . } \\
\hline
\end{tabular}

The researcher and another trained Iranian EFL teacher independently rated $50 \%$ of the speaking data randomly. The percentage agreement turned out to be $94 \%$. All disagreements were then resolved through discussion. The researcher then rated the remaining data. In order to avoid coding towards expectations (Révész, 2012), the second rater was 'blinded' about the learners and the purpose of the study. Inter-coder reliability scores were calculated using Cohen's kappa co-efficient (к). Overall, the percentage agreement was .96 , showing satisfactory reliability.

\section{Researcher's Awareness Pamphlet}

As the main concern of the present study is to examine the effect of transformative and contemplative teaching approaches on learners' speaking performance, it is felt necessary to familiarize the teachers with the scopes of transformative and contemplative teaching. For this purpose, a pamphlet was composed and given to teachers let them figure out the meaning of transformation and contemplation and the relative techniques and strategies needed to be administered in the classes. Moreover, the researcher clarified and crystallized the domain of the study for teachers who cooperated in scores assessment in a separate session.

\section{Post- Test}

In order to analyze learners' speaking progression after the treatment process, one more version of PET test was used. The total score of learners' speaking performances was evaluated based on the score band list mentioned above. It needs to be noted that the inter-rater reliability of the speaking post-test was estimated to be .93 using Cohen's kappa co-efficient. 


\section{Attitude Interview}

Since the last two research questions of the present study deal with EFL learners' attitudes toward the two teaching approaches after getting the treatment of contemplative and transformative teaching approaches, a semi-structured interview was designed based on Gardner's attitude motivation test AMTB (2004, Appendix ). The questions asked about the efficacy of each teaching approach, the barriers in their implementations, ways to improve them and learners' preferences towards them. A digital voice recorder was used to audio record learners' responses to the interview questions by permission. Cohen's kappa coefficient was used to examine the inter-rater reliability of the interviews between the researcher and a second trained rater on $20 \%$ of the data. The resulting value $(\kappa=.89)$ confirmed the agreement between the raters.

\section{Transformative Questionnaire}

In addition to the interview, a questionnaire was designed based on the Gardner's attitude motivation test AMTB investigating learners' attitudes and motivation towards the transformative teaching approach. The questionnaire included 20 5- point Likert-scale items ranging from "Strongly Disagree" to "Strongly Agree" with values 1-5 assigned to each alternative items with the scales ranging from strongly agree to strongly disagree (Appendix B). The reliability of the questionnaire was analyzed through Cronbach's alpha $(a=.90)$.

\section{Contemplative Questionnaire}

Another questionnaire was also developed in accordance with Gardner's attitude motivation test AMTB investigating learners' attitudes and motivation towards the contemplative teaching approach. The questionnaire also comprised 20 Likert-scale items varying from "Strongly Disagree" to "Strongly Agree" with values 1-5 assigned to each alternative items with the scales ranging from strongly agree to strongly disagree (Appendix C). The reliability of the questionnaire was analyzed through Cronbach's alpha $(a=$ 89).

\section{Procedure}

The study primarily started by the choice of the language school and negotiations with the authorities. After coming up with agreement, two intermediate classes (two intact groups) were selected based on convenient and purposeful sampling techniques. The study was carried out based on the following stepwise procedures:

\section{Homogenization}

In order to get assured of the homogeneity of the participants, a standardized version of Preliminary English Test (PET) was administered.

\section{Classification}


Getting assured of the homogeneity of the participants, the participants were divided into two groups randomly. The two classes then were named as Group A (Experimental Group 1) and Group B (Experimental Group 2). The total number of students in the two groups altogether was 41 intermediate EFL learners.

\section{Pretesting}

The two selected groups were administered the speaking section of PET test. This test served as the pretest. The scores obtained in pretest to measure speaking ability of the participants were measured by means of the designed score band list.

\section{Treatment}

Two classes received treatment for almost 2 months, that is, 10 sessions. During this period, group A received contemplative practices through a number of options such as journaling, attitude communication, vision setting, and so forth according to Scida and Jones (2017). In this group, the teacher implemented a brief mindfulness practice (e.g., meditation; a breathing exercise; a moment for quiet reflection) into the beginning of every class to help learners reset and prepare to be fully present. Group B received transformative practices through directing learners to understand another's meaning through speech, real-life role plays, various scenarios, drama among others. Every single change was recorded by the inquirer for later interpretation.

\section{Post testing}

For analyzing the effects of treatments during 2 months, a parallel speaking section of PET was administered to students to measure the amount of changes in students' speaking ability. Students' scores were measured according to inter -rater consistency and the teacher is able to consider an appropriate score based on students' abilities.

\section{Interviewing}

Interviews were semi-structured in nature and were conducted to find out how students felt about contemplative teaching and transformative learning. The interview questions attempted to tap the participants' attitudes towards these innovative instructional approaches in their classroom and their suggestions for ways to improve them.

\section{Results}

In order to investigate the first research question concerned with the effectiveness of contemplative teaching approach, a paired samples $t$-test was conducted comparing the pretest and posttest performance of the participants in this group. The results of descriptive statistics are shown in Table 2 and the results of t-test are presented in Table 3. 
Table 2. Descriptive Statistics for Contemplative Group

\begin{tabular}{|llllll|}
\hline & & Mean & N & Std. Deviation & Std. Error Mean \\
\hline Pair 1 & pretest & 2.6667 & 21 & 1.06458 & .23231 \\
\cline { 2 - 6 } & posttest & 2.3810 & 21 & 1.16087 & .25332 \\
\hline
\end{tabular}

As the mean and standard deviation scores in Table 2 illuminate, there are non-significant differences between the contemplative group learners' pretest and posttest speaking performance. However, in order to get more accurate results, a paired samples $t$-test was conducted, the results of which are demonstrated in Table 3.

Table 3. T-test Results for Contemplative Group

\begin{tabular}{|c|c|c|c|c|c|c|c|c|c|}
\hline & & \multicolumn{5}{|c|}{ Paired Differences } & \multirow[t]{3}{*}{$\mathbf{t}$} & \multirow[t]{3}{*}{ df } & \multirow{3}{*}{$\begin{array}{l}\text { Sig. } \\
(2- \\
\text { tailed) }\end{array}$} \\
\hline & & \multirow[t]{2}{*}{ Mean } & \multirow[t]{2}{*}{$\begin{array}{l}\text { Std. } \\
\text { Deviation }\end{array}$} & \multirow[t]{2}{*}{$\begin{array}{l}\text { Std. } \\
\text { Error } \\
\text { Mean }\end{array}$} & \multicolumn{2}{|c|}{$\begin{array}{l}95 \% \text { Confidence } \\
\text { Interval of the } \\
\text { Difference }\end{array}$} & & & \\
\hline & & & & & Lower & Upper & & & \\
\hline $\begin{array}{l}\text { Pair } \\
1\end{array}$ & $\begin{array}{l}\text { pretest - } \\
\text { posttest }\end{array}$ & .28571 & 1.41926 & .30971 & -.36032 & .93175 & .923 & 20 & .367 \\
\hline
\end{tabular}

The results of paired samples $t$-test show statistically non-significant differences, $t(20)=.92, p=.37, d$ $=.25$ between the pretest and posttest performances. This result means that the use of contemplative approach did not lead to any changes in learners' speaking development.

In order to provide an answer to the second research question of the study which asked about the role of transformative approach in participants' speaking performance, a paired samples $t$-test was carried out. First, the results of descriptive statistics are indicated in Table 4.

Table 4. Descriptive Statistics for Transformative Group

\begin{tabular}{|llllll|}
\hline & & Mean & N & Std. Deviation & Std. Error Mean \\
\hline Pair 1 & pretest & 2.9000 & 20 & 1.25237 & .28004 \\
\cline { 2 - 6 } & posttest & 3.7500 & 20 & 1.01955 & .22798 \\
\hline
\end{tabular}

As Table 4 exhibits, the mean of posttest $(M=3.75, S D=1.01)$ is higher than that of the pretest $(M=2.90$, $S D=1.25)$ considering speaking performance. Below are the results of $t$-test to achieve more exact 
findings.

Table 5. T-test Results for Transformative Group

\begin{tabular}{|c|c|c|c|c|c|c|c|c|c|}
\hline & & \multicolumn{5}{|c|}{ Paired Differences } & \multirow[t]{3}{*}{$\mathrm{t}$} & \multirow[t]{3}{*}{ df } & \multirow{3}{*}{$\begin{array}{l}\text { Sig. } \\
(2- \\
\text { tailed) }\end{array}$} \\
\hline & & \multirow[t]{2}{*}{ Mean } & \multirow[t]{2}{*}{$\begin{array}{l}\text { Std. } \\
\text { Deviation }\end{array}$} & \multirow[t]{2}{*}{$\begin{array}{l}\text { Std. } \\
\text { Error } \\
\text { Mean }\end{array}$} & \multicolumn{2}{|c|}{$\begin{array}{l}95 \% \text { Confidence } \\
\text { Interval of the } \\
\text { Difference }\end{array}$} & & & \\
\hline & & & & & Lower & Upper & & & \\
\hline $\begin{array}{l}\text { Pair } \\
1\end{array}$ & $\begin{array}{l}\text { pretest - } \\
\text { posttest }\end{array}$ & -.85000 & 1.42441 & .31851 & -1.51664 & -.18336 & -2.669 & 19 & .015 \\
\hline
\end{tabular}

The results of $t$-test show a statistically significant difference, $t(19)=-2.66, p=.015, d=.74$, between the pretest and posttest speaking performance of the transformative group learners.

In order to provide an answer to the third research question about the participants' attitudes to contemplative teaching approach, their questionnaire outcomes and the results of semi-structured in interviews were analyzed. The extra detail and richness provided by the retrospective data enabled clarification of attitudes towards the use of different instructional approaches for the purpose of improving speaking skill. For the qualitative questions of the study, participants' replies were investigated descriptively though interpretive content analysis.

Participants welcomed the contemplative teaching approach and expressed different opinions in their interviews. For instance, one participant said that "the teacher involved us in a three-minute breathing meditation and after that we had gratitude practices and a short deep speaking activity about the highs and lows of the week. I really liked this experience and I was in fact looking forward to it all week". Likewise, another participant added that "this practice helped me feel more concentrated and connected and less anxious during class". More importantly, a participant stressed that this approach "made me relaxed and helped me engage in the speaking activities more because it reduced my stress". And, one other learner explicated that "I have experienced empathy and kindness, and I really appreciated the way it felt." Nevertheless, many learners found this approach "weird", "unusual", "ineffective", and "a waste of time". For example, one learner stated that he "was skeptical of changing more familiar teaching and learning methods which I think are more useful". Another interviewee clarified that "it did not make me more aware of my weaknesses in English and I don't think that I was reflective about what I was doing and why." Another important idea that emerged from the interviews was that during the deep speaking activities which encouraged learners to express their own thoughts, they could not communicate with their peers in effective ways. One participant asserted "I could not get the support of my classmate to do the speaking activity". He went on to add that "it was calming but we did not understand how to do the activity successfully and there were many ambiguities". The results of the interviews are in fact in line 
with those obtained from the questionnaires. These opinions are also in line with the participants' selfreports in their questionnaires as depicted in Table 6.

Table 6 Contemplative Questionnaire Results 


\begin{tabular}{|c|c|c|c|c|c|}
\hline Items & & Frequency & Percent & Valid Percent & Cumulative Percent \\
\hline \multirow[t]{5}{*}{1} & disagree & 7 & 33.3 & 33.3 & 33.3 \\
\hline & neither disagree nor agree & 4 & 19.0 & 19.0 & 52.4 \\
\hline & agree & 6 & 28.6 & 28.6 & 81.0 \\
\hline & strongly agree & 4 & 19.0 & 19.0 & 100.0 \\
\hline & Total & 21 & 100.0 & 100.0 & \\
\hline \multirow[t]{6}{*}{2} & strongly disagree & 1 & 4.8 & 4.8 & 4.8 \\
\hline & disagree & 1 & 4.8 & 4.8 & 9.5 \\
\hline & neither disagree nor agree & 3 & 14.3 & 14.3 & 23.8 \\
\hline & agree & 7 & 33.3 & 33.3 & 57.1 \\
\hline & strongly agree & 9 & 42.9 & 42.9 & 100.0 \\
\hline & Total & 21 & 100.0 & 100.0 & \\
\hline \multirow[t]{6}{*}{3} & strongly disagree & 1 & 4.8 & 4.8 & 4.8 \\
\hline & disagree & 3 & 14.3 & 14.3 & 19.0 \\
\hline & neither disagree nor agree & 4 & 19.0 & 19.0 & 38.1 \\
\hline & agree & 7 & 33.3 & 33.3 & 71.4 \\
\hline & strongly agree & 6 & 28.6 & 28.6 & 100.0 \\
\hline & Total & 21 & 100.0 & 100.0 & \\
\hline \multirow[t]{6}{*}{4} & strongly disagree & 2 & 9.5 & 9.5 & 9.5 \\
\hline & disagree & 9 & 42.9 & 42.9 & 52.4 \\
\hline & neither disagree nor agree & 7 & 33.3 & 33.3 & 85.7 \\
\hline & agree & 2 & 9.5 & 9.5 & 95.2 \\
\hline & strongly agree & 1 & 4.8 & 4.8 & 100.0 \\
\hline & Total & 21 & 100.0 & 100.0 & \\
\hline \multirow[t]{5}{*}{5} & strongly disagree & 9 & 42.9 & 42.9 & 42.9 \\
\hline & disagree & 6 & 28.6 & 28.6 & 71.4 \\
\hline & neither disagree nor agree & 2 & 9.5 & 9.5 & 81.0 \\
\hline & agree & 2 & 9.5 & 9.5 & 90.5 \\
\hline & strongly agree & 2 & 9.5 & 9.5 & 100.0 \\
\hline
\end{tabular}




\begin{tabular}{|c|c|c|c|c|c|}
\hline \multicolumn{2}{|c|}{ Items } & \multirow{2}{*}{$\begin{array}{l}\text { Frequency } \\
21\end{array}$} & \multirow{2}{*}{$\begin{array}{l}\text { Percent } \\
100.0\end{array}$} & \multirow{2}{*}{$\begin{array}{l}\text { Valid Percent } \\
100.0\end{array}$} & \multirow[t]{2}{*}{ Cumulative Percent } \\
\hline & Total & & & & \\
\hline \multirow[t]{4}{*}{6} & strongly disagree & 7 & 33.3 & 33.3 & 33.3 \\
\hline & disagree & 8 & 38.1 & 38.1 & 71.4 \\
\hline & neither disagree nor agree & 6 & 28.6 & 28.6 & 100.0 \\
\hline & Total & 21 & 100.0 & 100.0 & \\
\hline \multirow[t]{6}{*}{7} & strongly disagree & 6 & 28.6 & 28.6 & 28.6 \\
\hline & disagree & 7 & 33.3 & 33.3 & 61.9 \\
\hline & neither disagree nor agree & 4 & 19.0 & 19.0 & 81.0 \\
\hline & agree & 2 & 9.5 & 9.5 & 90.5 \\
\hline & strongly agree & 2 & 9.5 & 9.5 & 100.0 \\
\hline & Total & 21 & 100.0 & 100.0 & \\
\hline \multirow[t]{5}{*}{8} & strongly disagree & 8 & 38.1 & 38.1 & 38.1 \\
\hline & disagree & 7 & 33.3 & 33.3 & 71.4 \\
\hline & neither disagree nor agree & 5 & 23.8 & 23.8 & 95.2 \\
\hline & agree & 1 & 4.8 & 4.8 & 100.0 \\
\hline & Total & 21 & 100.0 & 100.0 & \\
\hline \multirow[t]{5}{*}{9} & strongly disagree & 7 & 33.3 & 33.3 & 33.3 \\
\hline & disagree & 9 & 42.9 & 42.9 & 76.2 \\
\hline & neither disagree nor agree & 4 & 19.0 & 19.0 & 95.2 \\
\hline & agree & 1 & 4.8 & 4.8 & 100.0 \\
\hline & Total & 21 & 100.0 & 100.0 & \\
\hline \multirow[t]{6}{*}{10} & strongly disagree & 6 & 28.6 & 28.6 & 28.6 \\
\hline & disagree & 5 & 23.8 & 23.8 & 52.4 \\
\hline & neither disagree nor agree & 5 & 23.8 & 23.8 & 76.2 \\
\hline & agree & 3 & 14.3 & 14.3 & 90.5 \\
\hline & strongly agree & 2 & 9.5 & 9.5 & 100.0 \\
\hline & Total & 21 & 100.0 & 100.0 & \\
\hline 11 & strongly disagree & 6 & 28.6 & 28.6 & 28.6 \\
\hline
\end{tabular}




\begin{tabular}{|c|c|c|c|c|c|}
\hline \multicolumn{2}{|c|}{ Items } & \multirow{2}{*}{$\begin{array}{l}\text { Frequency } \\
10\end{array}$} & \multirow{2}{*}{$\begin{array}{l}\text { Percent } \\
47.6\end{array}$} & \multirow{2}{*}{$\begin{array}{l}\text { Valid Percent } \\
47.6\end{array}$} & \multirow{2}{*}{$\begin{array}{l}\text { Cumulative Percent } \\
76.2\end{array}$} \\
\hline & disagree & & & & \\
\hline & neither disagree nor agree & 5 & 23.8 & 23.8 & 100.0 \\
\hline & Total & 21 & 100.0 & 100.0 & \\
\hline \multirow[t]{4}{*}{12} & strongly disagree & 8 & 38.1 & 38.1 & 38.1 \\
\hline & disagree & 11 & 52.4 & 52.4 & 90.5 \\
\hline & neither disagree nor agree & 2 & 9.5 & 9.5 & 100.0 \\
\hline & Total & 21 & 100.0 & 100.0 & \\
\hline \multirow[t]{6}{*}{13} & strongly disagree & 5 & 23.8 & 23.8 & 23.8 \\
\hline & disagree & 8 & 38.1 & 38.1 & 61.9 \\
\hline & neither disagree nor agree & 5 & 23.8 & 23.8 & 85.7 \\
\hline & agree & 2 & 9.5 & 9.5 & 95.2 \\
\hline & strongly agree & 1 & 4.8 & 4.8 & 100.0 \\
\hline & Total & 21 & 100.0 & 100.0 & \\
\hline \multirow[t]{6}{*}{14} & strongly disagree & 4 & 19.0 & 19.0 & 19.0 \\
\hline & disagree & 8 & 38.1 & 38.1 & 57.1 \\
\hline & neither disagree nor agree & 3 & 14.3 & 14.3 & 71.4 \\
\hline & agree & 3 & 14.3 & 14.3 & 85.7 \\
\hline & strongly agree & 3 & 14.3 & 14.3 & 100.0 \\
\hline & Total & 21 & 100.0 & 100.0 & \\
\hline \multirow[t]{6}{*}{15} & strongly disagree & 1 & 4.8 & 4.8 & 4.8 \\
\hline & disagree & 3 & 14.3 & 14.3 & 19.0 \\
\hline & neither disagree nor agree & 4 & 19.0 & 19.0 & 38.1 \\
\hline & agree & 9 & 42.9 & 42.9 & 81.0 \\
\hline & strongly agree & 4 & 19.0 & 19.0 & 100.0 \\
\hline & Total & 21 & 100.0 & 100.0 & \\
\hline \multirow[t]{3}{*}{16} & strongly disagree & 1 & 4.8 & 4.8 & 4.8 \\
\hline & disagree & 10 & 47.6 & 47.6 & 52.4 \\
\hline & neither disagree nor agree & 7 & 33.3 & 33.3 & 85.7 \\
\hline
\end{tabular}




\begin{tabular}{|c|c|c|c|c|c|}
\hline \multicolumn{2}{|c|}{ Items } & \multirow{2}{*}{$\begin{array}{l}\text { Frequency } \\
3\end{array}$} & \multirow{2}{*}{$\begin{array}{l}\text { Percent } \\
14.3\end{array}$} & \multirow{2}{*}{$\begin{array}{l}\text { Valid Percent } \\
14.3\end{array}$} & \multirow{2}{*}{$\begin{array}{l}\text { Cumulative Percent } \\
100.0\end{array}$} \\
\hline & agree & & & & \\
\hline & Total & 21 & 100.0 & 100.0 & \\
\hline \multirow[t]{6}{*}{17} & strongly disagree & 1 & 4.8 & 4.8 & 4.8 \\
\hline & disagree & 2 & 9.5 & 9.5 & 14.3 \\
\hline & neither disagree nor agree & 4 & 19.0 & 19.0 & 33.3 \\
\hline & agree & 7 & 33.3 & 33.3 & 66.7 \\
\hline & strongly agree & 7 & 33.3 & 33.3 & 100.0 \\
\hline & Total & 21 & 100.0 & 100.0 & \\
\hline \multirow[t]{6}{*}{18} & strongly disagree & 6 & 28.6 & 28.6 & 28.6 \\
\hline & disagree & 6 & 28.6 & 28.6 & 57.1 \\
\hline & neither disagree nor agree & 1 & 4.8 & 4.8 & 61.9 \\
\hline & agree & 2 & 9.5 & 9.5 & 71.4 \\
\hline & strongly agree & 6 & 28.6 & 28.6 & 100.0 \\
\hline & Total & 21 & 100.0 & 100.0 & \\
\hline \multirow[t]{6}{*}{19} & strongly disagree & 2 & 9.5 & 9.5 & 9.5 \\
\hline & disagree & 4 & 19.0 & 19.0 & 28.6 \\
\hline & neither disagree nor agree & 5 & 23.8 & 23.8 & 52.4 \\
\hline & agree & 7 & 33.3 & 33.3 & 85.7 \\
\hline & strongly agree & 3 & 14.3 & 14.3 & 100.0 \\
\hline & Total & 21 & 100.0 & 100.0 & \\
\hline \multirow[t]{6}{*}{20} & strongly disagree & 7 & 33.3 & 33.3 & 33.3 \\
\hline & disagree & 10 & 47.6 & 47.6 & 81.0 \\
\hline & neither disagree nor agree & 2 & 9.5 & 9.5 & 90.5 \\
\hline & agree & 1 & 4.8 & 4.8 & 95.2 \\
\hline & strongly agree & 1 & 4.8 & 4.8 & 100.0 \\
\hline & Total & 21 & 100.0 & 100.0 & \\
\hline
\end{tabular}


The last research question asked about the participants' attitudes towards the transformative instructional approach. A large number of learners' expressed positive attitudes to this approach. One participant noted that "in this class, I was able to share knowledge, take on responsibility, and negotiate with my peers that could help me in solving problems and completing assignments". Another learner said that "having the opportunity to complete the assignments at my own pace provided more room for me to give attention to the details and be content with my final outcome". Others also declared that "doing the assignments in line with their interests", "being given numerous topics or assignment options that all fulfill a specific task", "performing activities based on my interests and priorities", and "being given activities to do outside the classroom" helped learners to have more opportunities for self-directed and self-paced learning. one participant appreciated "the use of answering questions and debating perspectives which I think gave me consciousness about different angles of the topic and how others might think differently". Furthermore, another learner mentioned that she "enjoyed role-playing interactions or situations that made me put myself in real-world contexts and use the language in ways that I know I will use in the future". And, one learner emphasized that "analyzing and reacting to materials in the classroom helped me get a thorough understand". It appeared that shaping the course content according to the learners' input, preferences, and needs resulted in their enjoyment and speaking performance as was revealed by the statistical analyses reported above. On the whole learners stated that different evaluation activities in this class were effective: "developing exam questions helped me synthesize or integrate information in completely novel ways", "allowing us to consult with a peer during an exam was unexpected but fruitful in my idea", "having the opportunity to correct and resubmit answers for an exam was motivating", "being able to revise and resubmit my exam papers after using the feedback or talking with the instructor helped me a lot in building on my knowledge". Results of the questionnaire analysis are provided in Table 7 which lend support to the participants' overall positive opinions about transformative teaching.

Table 7. Transformative Questionnaire Results 


\begin{tabular}{|c|c|c|c|c|c|}
\hline Items & & Frequency & Percent & Valid Percent & Cumulative Percent \\
\hline \multirow[t]{6}{*}{1} & strongly disagree & 2 & 10.0 & 10.0 & 10.0 \\
\hline & disagree & 3 & 15.0 & 15.0 & 25.0 \\
\hline & neither disagree nor agree & 3 & 15.0 & 15.0 & 40.0 \\
\hline & agree & 4 & 20.0 & 20.0 & 60.0 \\
\hline & strongly agree & 8 & 40.0 & 40.0 & 100.0 \\
\hline & Total & 20 & 100.0 & 100.0 & \\
\hline \multirow[t]{6}{*}{2} & strongly disagree & 2 & 10.0 & 10.0 & 10.0 \\
\hline & disagree & 4 & 20.0 & 20.0 & 30.0 \\
\hline & neither disagree nor agree & 6 & 30.0 & 30.0 & 60.0 \\
\hline & agree & 4 & 20.0 & 20.0 & 80.0 \\
\hline & strongly agree & 4 & 20.0 & 20.0 & 100.0 \\
\hline & Total & 20 & 100.0 & 100.0 & \\
\hline \multirow[t]{5}{*}{3} & strongly disagree & 6 & 30.0 & 30.0 & 30.0 \\
\hline & disagree & 9 & 45.0 & 45.0 & 75.0 \\
\hline & neither disagree nor agree & 4 & 20.0 & 20.0 & 95.0 \\
\hline & agree & 1 & 5.0 & 5.0 & 100.0 \\
\hline & Total & 20 & 100.0 & 100.0 & \\
\hline \multirow[t]{6}{*}{4} & strongly disagree & 2 & 10.0 & 10.0 & 10.0 \\
\hline & disagree & 3 & 15.0 & 15.0 & 25.0 \\
\hline & neither disagree nor agree & 4 & 20.0 & 20.0 & 45.0 \\
\hline & agree & 7 & 35.0 & 35.0 & 80.0 \\
\hline & strongly agree & 4 & 20.0 & 20.0 & 100.0 \\
\hline & Total & 20 & 100.0 & 100.0 & \\
\hline \multirow[t]{5}{*}{5} & strongly disagree & 2 & 10.0 & 10.0 & 10.0 \\
\hline & disagree & 3 & 15.0 & 15.0 & 25.0 \\
\hline & neither disagree nor agree & 3 & 15.0 & 15.0 & 40.0 \\
\hline & agree & 6 & 30.0 & 30.0 & 70.0 \\
\hline & strongly agree & 6 & 30.0 & 30.0 & 100.0 \\
\hline
\end{tabular}




\begin{tabular}{|c|c|c|c|c|c|}
\hline Items & & Frequency & Percent & Valid Percent & Cumulative Percent \\
\hline & Total & 20 & 100.0 & 100.0 & \\
\hline \multirow[t]{6}{*}{6} & strongly disagree & 3 & 15.0 & 15.0 & 15.0 \\
\hline & disagree & 4 & 20.0 & 20.0 & 35.0 \\
\hline & neither disagree nor agree & 6 & 30.0 & 30.0 & 65.0 \\
\hline & agree & 5 & 25.0 & 25.0 & 90.0 \\
\hline & strongly agree & 2 & 10.0 & 10.0 & 100.0 \\
\hline & Total & 20 & 100.0 & 100.0 & \\
\hline \multirow[t]{6}{*}{7} & strongly disagree & 1 & 5.0 & 5.0 & 5.0 \\
\hline & disagree & 4 & 20.0 & 20.0 & 25.0 \\
\hline & neither disagree nor agree & 7 & 35.0 & 35.0 & 60.0 \\
\hline & agree & 4 & 20.0 & 20.0 & 80.0 \\
\hline & strongly agree & 4 & 20.0 & 20.0 & 100.0 \\
\hline & Total & 20 & 100.0 & 100.0 & \\
\hline \multirow[t]{6}{*}{8} & strongly disagree & 1 & 5.0 & 5.0 & 5.0 \\
\hline & disagree & 3 & 15.0 & 15.0 & 20.0 \\
\hline & neither disagree nor agree & 6 & 30.0 & 30.0 & 50.0 \\
\hline & agree & 6 & 30.0 & 30.0 & 80.0 \\
\hline & strongly agree & 4 & 20.0 & 20.0 & 100.0 \\
\hline & Total & 20 & 100.0 & 100.0 & \\
\hline \multirow[t]{6}{*}{9} & strongly disagree & 2 & 10.0 & 10.0 & 10.0 \\
\hline & disagree & 3 & 15.0 & 15.0 & 25.0 \\
\hline & neither disagree nor agree & 3 & 15.0 & 15.0 & 40.0 \\
\hline & agree & 7 & 35.0 & 35.0 & 75.0 \\
\hline & strongly agree & 5 & 25.0 & 25.0 & 100.0 \\
\hline & Total & 20 & 100.0 & 100.0 & \\
\hline \multirow[t]{3}{*}{10} & strongly disagree & 4 & 20.0 & 20.0 & 20.0 \\
\hline & disagree & 6 & 30.0 & 30.0 & 50.0 \\
\hline & neither disagree nor agree & 4 & 20.0 & 20.0 & 70.0 \\
\hline
\end{tabular}




\begin{tabular}{|c|c|c|c|c|c|}
\hline \multicolumn{2}{|c|}{ Items } & \multirow{2}{*}{$\begin{array}{l}\text { Frequency } \\
4\end{array}$} & \multirow{2}{*}{$\begin{array}{l}\text { Percent } \\
20.0\end{array}$} & \multirow{2}{*}{$\begin{array}{l}\text { Valid Percent } \\
20.0\end{array}$} & \multirow{2}{*}{$\begin{array}{l}\text { Cumulative Percent } \\
90.0\end{array}$} \\
\hline & agree & & & & \\
\hline & strongly agree & 2 & 10.0 & 10.0 & 100.0 \\
\hline & Total & 20 & 100.0 & 100.0 & \\
\hline \multirow[t]{6}{*}{11} & strongly disagree & 1 & 5.0 & 5.0 & 5.0 \\
\hline & disagree & 2 & 10.0 & 10.0 & 15.0 \\
\hline & neither disagree nor agree & 7 & 35.0 & 35.0 & 50.0 \\
\hline & agree & 8 & 40.0 & 40.0 & 90.0 \\
\hline & strongly agree & 2 & 10.0 & 10.0 & 100.0 \\
\hline & Total & 20 & 100.0 & 100.0 & \\
\hline \multirow[t]{6}{*}{12} & strongly disagree & 1 & 5.0 & 5.0 & 5.0 \\
\hline & disagree & 1 & 5.0 & 5.0 & 10.0 \\
\hline & neither disagree nor agree & 4 & 20.0 & 20.0 & 30.0 \\
\hline & agree & 7 & 35.0 & 35.0 & 65.0 \\
\hline & strongly agree & 7 & 35.0 & 35.0 & 100.0 \\
\hline & Total & 20 & 100.0 & 100.0 & \\
\hline \multirow[t]{6}{*}{13} & strongly disagree & 1 & 5.0 & 5.0 & 5.0 \\
\hline & disagree & 2 & 10.0 & 10.0 & 15.0 \\
\hline & neither disagree nor agree & 3 & 15.0 & 15.0 & 30.0 \\
\hline & agree & 8 & 40.0 & 40.0 & 70.0 \\
\hline & strongly agree & 6 & 30.0 & 30.0 & 100.0 \\
\hline & Total & 20 & 100.0 & 100.0 & \\
\hline \multirow[t]{6}{*}{14} & strongly disagree & 1 & 5.0 & 5.0 & 5.0 \\
\hline & disagree & 1 & 5.0 & 5.0 & 10.0 \\
\hline & neither disagree nor agree & 4 & 20.0 & 20.0 & 30.0 \\
\hline & agree & 7 & 35.0 & 35.0 & 65.0 \\
\hline & strongly agree & 7 & 35.0 & 35.0 & 100.0 \\
\hline & Total & 20 & 100.0 & 100.0 & \\
\hline 15 & strongly disagree & 2 & 10.0 & 10.0 & 10.0 \\
\hline
\end{tabular}




\begin{tabular}{|c|c|c|c|c|c|}
\hline \multicolumn{2}{|c|}{ Items } & \multirow{2}{*}{$\begin{array}{l}\text { Frequency } \\
2\end{array}$} & \multirow{2}{*}{$\begin{array}{l}\text { Percent } \\
10.0\end{array}$} & \multirow{2}{*}{$\begin{array}{l}\text { Valid Percent } \\
10.0\end{array}$} & \multirow{2}{*}{$\begin{array}{l}\text { Cumulative Percent } \\
20.0\end{array}$} \\
\hline & disagree & & & & \\
\hline & neither disagree nor agree & 5 & 25.0 & 25.0 & 45.0 \\
\hline & agree & 6 & 30.0 & 30.0 & 75.0 \\
\hline & strongly agree & 5 & 25.0 & 25.0 & 100.0 \\
\hline & Total & 20 & 100.0 & 100.0 & \\
\hline \multirow[t]{6}{*}{16} & strongly disagree & 6 & 30.0 & 30.0 & 30.0 \\
\hline & disagree & 10 & 50.0 & 50.0 & 80.0 \\
\hline & neither disagree nor agree & 2 & 10.0 & 10.0 & 90.0 \\
\hline & agree & 1 & 5.0 & 5.0 & 95.0 \\
\hline & strongly agree & 1 & 5.0 & 5.0 & 100.0 \\
\hline & Total & 20 & 100.0 & 100.0 & \\
\hline \multirow[t]{6}{*}{17} & strongly disagree & 4 & 20.0 & 20.0 & 20.0 \\
\hline & disagree & 9 & 45.0 & 45.0 & 65.0 \\
\hline & neither disagree nor agree & 3 & 15.0 & 15.0 & 80.0 \\
\hline & agree & 2 & 10.0 & 10.0 & 90.0 \\
\hline & strongly agree & 2 & 10.0 & 10.0 & 100.0 \\
\hline & Total & 20 & 100.0 & 100.0 & \\
\hline \multirow[t]{6}{*}{18} & strongly disagree & 5 & 25.0 & 25.0 & 25.0 \\
\hline & disagree & 9 & 45.0 & 45.0 & 70.0 \\
\hline & neither disagree nor agree & 4 & 20.0 & 20.0 & 90.0 \\
\hline & agree & 1 & 5.0 & 5.0 & 95.0 \\
\hline & strongly agree & 1 & 5.0 & 5.0 & 100.0 \\
\hline & Total & 20 & 100.0 & 100.0 & \\
\hline \multirow[t]{5}{*}{19} & strongly disagree & 4 & 20.0 & 20.0 & 20.0 \\
\hline & disagree & 7 & 35.0 & 35.0 & 55.0 \\
\hline & neither disagree nor agree & 6 & 30.0 & 30.0 & 85.0 \\
\hline & agree & 2 & 10.0 & 10.0 & 95.0 \\
\hline & strongly agree & 1 & 5.0 & 5.0 & 100.0 \\
\hline
\end{tabular}




\begin{tabular}{|c|c|c|c|c|c|}
\hline \multicolumn{2}{|c|}{ Items } & \multirow{2}{*}{$\begin{array}{l}\text { Frequency } \\
20\end{array}$} & \multirow{2}{*}{$\begin{array}{l}\text { Percent } \\
100.0\end{array}$} & \multirow{2}{*}{$\begin{array}{l}\text { Valid Percent } \\
100.0\end{array}$} & \multirow[t]{2}{*}{ Cumulative Percent } \\
\hline & Total & & & & \\
\hline \multirow[t]{6}{*}{20} & strongly disagree & 1 & 5.0 & 5.0 & 5.0 \\
\hline & disagree & 3 & 15.0 & 15.0 & 20.0 \\
\hline & neither disagree nor agree & 3 & 15.0 & 15.0 & 35.0 \\
\hline & agree & 10 & 50.0 & 50.0 & 85.0 \\
\hline & strongly agree & 3 & 15.0 & 15.0 & 100.0 \\
\hline & Total & 20 & 100.0 & 100.0 & \\
\hline
\end{tabular}

\section{Discussion}

The present study was aimed at comparing the role of two new approaches to teaching speaking in Iran: contemplative and transformative. Results revealed that the contemplative teaching was not effective in comparison to the transformative approach in enhancing the learners' speaking skills. Contemplative teaching is argued to present an educational vision with the purpose of both individual and societal change (Byrnes, 2012). Contemplative teaching, in other words, is "a set of pedagogical practices, originally developed in the great contemplative traditions of the world, that have as their aim personal growth and social transformation through the cultivation of conscious awareness and volition in an ethical-relational context" (Roeser \& Peck, 2009, pp. 119-120). There have been lots of attention directed to contemplative teaching in recent years by both practitioners and researchers due to its focus on wholeness and potential for change, which is in fact opposite to many contemporary mainstream educational practices that underline isolated knowledge and transmission. Contemplative teaching, akin to contemplative understanding, is an approach to the processes of teaching and learning that is in accordance with wholeness (Byrnes, 2012). Therefore, it can be speculated that the Iranian EFL learners who are normally accustomed to the teacher-fronted approach to instruction where the teacher delivers the knowledge to the learners could not benefit from this practice and could not welcome it as was evident in the interview results as well.

Transformative approach on the other hand was effective in fostering the participants' speaking performance and was favored by the majority of learners. This finding is supported by previous research (e.g., Noland \& Richards, 2014; Slavich \& Zimbardo, 2012) illuminating the effectiveness of transformational teaching. And, the results of interviews confirmed that learners were more eager and motivated to learn with this approach. Importantly, it is argued that teachers in the transformative classroom focus on both the outcomes and also the processes to obtain them. This process establishes a meaningful and positive context in the classroom (Pounder, 2003). Transformational teachers emphasize the emotional aspects as well as linguistic performance. Studies have looked into the impact of affect on foregrounding other types of learning (Frymier, 1993). Actually, learner attitudes toward the 
classroom, teacher and content mediate learners' linguistic learning and performance (Rodriguez et al., 1996). Motivation and idealized impact are the cornerstones of transformational teaching that deal with affective aspects of teaching (Dionne et al., 2004). When learners are involved in the content being shared, they become more likely to engage in learning (Frymier, Shulman \& Houser, 1996). Intellectual stimulation and individualized attention significantly influence learners' learning (Noland, 2005). This result was approved in the present study was well: Teachers' focus on learners needs and advancement of novel approaches to coursework led to enhancement in learner interaction which affect learning (Avolio et al., 1991; Frymier et al., 1996).

\section{Conclusion}

The findings of this study verified the value of transformative teaching approach in enhancing the speaking skill. Dedicating time to interaction with learners individually can be achieved in several ways both inside and outside the classroom. For instance, meeting with learners after both poor and good results on an assignment to make them aware that the teacher is monitoring their performance, and taking the time both before and after class to interact with learners are some of the suggestions. In order to develop teachers as transformational practitioners, one can summarize transformational teaching in an easily comprehensible format such as using handouts or videos that demand minimal time or that can be read or watched in short intervals. These summaries can include the fundamental dimensions of transformational teaching, and can provide answers to the most common questions and issues and avoid anxiety in implementing a new teaching approach (Sadeghi \& Khezrlou, 2014, 2016; Sadeghi, Khezrlou \& Modirkhameneh, 2017). In sum, transformational teaching appears to address the major similarities that exist across the contemporary approaches to learning and classroom instruction. It is therefore suggested that it can be used as an innovative approach for thinking about how to enhance learners' speaking skill development.

Although the results of the present study are promising, there are a number of limitations that need to be borne in mind in the interpretation of the results. A central limitation in the study is the lack of a control group as a baseline to compare the results of experimental group with. Therefore, future studies are encouraged to use a refined approach to replicate this study. Another potential issue is the investigation of the speaking skill in the present study. In order to get more robust information about the suitability of this approach on the whole to teaching all four language skills, there is a need for further studies to explore this approach regarding the reading, writing and listening development as well. Furthermore, although the reliabilities of the instruments were all acceptable, further studies are encouraged to use other tools such as role plays, open discussions, storytelling to improve the clarity and validity of these results. Lastly, the sample was limited and was not diverse in terms of learner individual difference variables which inhibits the generalizability of the results to a larger population. This limitation is an important one considering the individual differences among the learners which call for more research in this area. 


\section{Declarations}

\section{Availability of data and materials:}

The dataset for this study can be provided upon request.

\section{Competing interests:}

The authors have no competing interests.

\section{Funding:}

This research is not funded by any institution.

\section{Authors' contributions:}

The present study is extracted from the PhD thesis of the first author and is written and prepared under the supervision of the second author.

\section{Acknowledgements:}

We would like to thank the participants who gave their valuable time to participate in this study.

\section{References}

1. Avolio, B. J., Waldman, D. A., \& Yammarino, F. J. (1991). Leading in the 1990's: The four i's of transformational leadership. Journal of European Industrial Training, 15, 9-16.

2. Baumgartner, L. M. (2012). Mezirow's theory of transformative learning from 1975 to present. In Taylor, E. W., Cranton, P. (Eds.), Handbook of transformative learning (pp. 99-115). San Francisco, CA: Jossey-Bass.

3. Belenky, M. F., Clinchy, B. M., Goldberger, N. R., \& Tarule, J. M. (1986). Women's ways of knowing: The development of self, voice and mind (New York, Basic Books).

4. Biggs, J. B. (1989). Approaches to the enhancement of tertiary teaching. Higher Education Research and Development, 8, 7-25.

5. Biggs, J. B. (1992). From theory to practice: A cognitive systems approach. Paper presented at the Annual Conference of the Higher Education Research and Development Society of Australasia, Churchill Campus, Monash University.

6. Bush, M. (2006). Introduction to a special issue on contemplative practices and education. In C. C. Hill (Ed.), Teachers college press (pp. 1723-1732). Oxford: Oxford University Press.

7. Byrnes, K. (2009). Portraits of contemplative teaching: A third way. Proquest Dissertations.

8. Byrnes, K. (2012). A Portrait of contemplate teaching. Journal of Transformative Education, 10 (1), 22-41. 
9. Castro, C. B., Perinan, M., M., V., \& Bueno, J. C. C. (2008). Transformational leadership and followers' attitudes: The mediating role of psychological empowerment. The International Journal of Human Resource Management, 19, 1842-1863.

10. Dam L., Eriksson, R., Little, D., Miliander, J., \& Trebbi, T. (1999). Towards a definition of autonomy. Third Nordic Workshop on Developing Autonomous Learning in the FL Classroom, Bergen University of Bergen.

11. D'Amato, L. G., \& Krasny, M. E. (2011). Outdoor adventure education: Applying transformative learning theory to understanding instrumental learning and personal growth in environmental education. The Journal of Environmental Education, 42(4), 237-254.

12. Dionne, S. D., Yammarino, F. J., Atwater, L. E., \& Spangler, W. D. (2004). Transformational leadership and team performance. Journal of Organizational Change Management, 17, 177-193.

13. Entwistle, N., Entwistle, A., \& Tait, H. (1991). Academic understanding and contexts to enhance it: a perspective from research on student learning. In T. M. Duffy, J. Lowych \& D. H. Jonasse N (Eds.), Designing environments for constructive learning (pp. 146-158). Berlin, Springer-Verlag.

14. Fisher-Yoshida, B., Geller, K. D., \& Schapiro, S. A. (2009). Introduction: New dimensions in transformative education. In B. Fisher-Yoshida, K. D. Geller, \& S. A. Schapiro (Eds.), Innovations in transformative learning: Space, culture, and the arts (pp. 1-19). New York, NY: Peter Lang.

15. Frymier, A. B. (1993). The impact of teacher immediacy on students' motivation: Is it the same for all students? Communication Quarterly, 41, 454-464.

16. Frymier, A. B., Shulman, G. M., \& Houser, M. L. (1996). The development of a learner empowerment measure. Communication Education, 45, 181-199.

17. Gardner, H. (2004). Mintea disciplinată: educaţia pe care o merită orice copil, dincolo de informaţii şi teste standardizate. Bucureşti: Editura Sigma.

18. Gyeltshen, Y. (2016). Contemplative practices and learning: A holistic approach to education in Bhutan. Doctoral Dissertations.

19. Goh, C. C. M., \& Burns, A. (2012). Teaching speaking: A holistic approach. New York: Cambridge University Press.

20. Johnson, K. (1996). Language teaching and skill learning. Oxford: Blackwell.

21. Khezrlou, S. (2020a). Training planning in second language narrative writing. ELT Journal, 74(1), 4962.

22. Khezrlou, S. (2020b). The role of task repetition with direct written corrective feedback in L2 writing complexity, accuracy and fluency. Journal of Second Language Studies, 3(1), 31-54.

23. Khezrlou, S. (2019a). Task repetition and corrective feedback: The role of feedback types and structure saliency. English Teaching and Learning, 43(2), 213-233.

24. Khezrlou, S. (2019b). Effects of timing and availability of isolated FFI on learners' written accuracy and fluency through task repetition. The Language Learning Journal. doi:

10.1080/09571736.2019.1656765

Page 25/32 
25. Khezrlou, S. (2019c). Form-focused instruction in CALL: What do learners think? RELC, 50(2), 235251.

26. Khezrlou, S. (2012a). Cognitive strategy training: Improving reading comprehension in the language classroom. Journal of Teaching Language Skills, 3(4), 77-98.

27. Khezrlou, S. (2012b). The relationship between cognitive and metacognitive strategies, age and level of education. The Reading Matrix, 12(1), 50-61.

28. Khezrlou, S., Ellis, R., \& Sadeghi, K. (2017). Effects of computer-assisted glosses on EFL learners' vocabulary acquisition and reading comprehension in three learning conditions. System, 65, 104-116.

29. Khezrlou, S., \& Sadeghi, K. (2012). Self-regulated vocabulary strategy use: Implications for CALL and individual variables. MEXTESOL Journal, 36(1), 1-17.

30. Little, D. (1991). Learner autonomy 1: Definitions, issues and problems. Dublin: Authentik.

31. Little, D. (2003). Learner autonomy and second/foreign language learning. Subject Centre for Languages, Linguistics and Area Studies Good Practice Guide. Retrieved May 30, 2020 from http://www.llas.ac.uk/resources/gpg/1409.

32. Marshall, J. D., Sears, T. J., Louise, A. A., Roberts, A. P., \& Schubert, H. W. (2007). Turning points in curriculum: A contemporary American memoir (2nd ed.). Upper Saddle River, NJ: Pearson.

33. Marton, F., Dall'alba, G., \& Beaty, E. (1993) Conceptions of learning. International Journal of Educational Research, 46, 4-11.

34. McDonough, K., \& Mackey, A. (Eds.) (2013). Second language interaction in diverse educational contexts. Amsterdam: John Benjamins.

35. Mezirow, J. (1997). Transformative learning: Theory to practice. Transformative Learning in Action: Insights from Practice. New directions in Adult and Continuing education. San Francisco: Jossey Bass.

36. Nitschke, P., \& Malvicini, P. (2013). Drawing toward transformation and action in forgotten barrio: Cultivating a learning and planning community. Journal of Transformative Education, 11(2), 127144.

37. Noland, A. K. (2005). The relationship between teacher transformational leadership and student outcomes. Miami University. Retrieved from http://rave.ohiolink.edu/etdc/view? acc_num=miami1123168677

38. Oliver, R., \& Philp, J. (2014). Focus on oral interaction. Oxford: Oxford University Press.

39. Perry, W. G. J. (1981) Cognitive and ethical growth: the making of meaning. In A. W. Chickering (Ed.), The modern American college (pp. 91-108). San Francisco, CA, Jossey-Boss.

40. Pounder, J. S. (2003). Employing transformational leadership to enhance the quality of management development instruction. Journal of Management Development, 22, 1-13.

41. Révész, A. (2012). Working memory and the observed effectiveness of recasts on different L2 outcome measures. Language Learning, 62(1), 93-132. 
42. Rodriguez, J., Plax, T. G., \& Kearney, P. (1996). Clarifying the relationship between teacher nonverbal immediacy and student cognitive learning: Affective learning as the central causal mediator. Communication Education, 45, 293-305.

43. Roeser, R. W., \& Peck, S. C. (2009). An education in awareness: Self, motivational and self-regulated learning in contemplative perspective. Educational Psychologist, 44, 119-136.

44. Sadeghi, K., \& Khezrlou, S. (2012). Glossing mode in self-regulated vocabulary learning, and its relationship with gender, age, and field of study. The Journal of Asia TEFL, 9(3), 51-74.

45. Sadeghi, K., \& Khezrlou, S. (2014). Burnout among English language teachers in Iran: Do sociodemographic characteristics matter? Procedia-Social and Behavioral Sciences, 98, 1590-1598.

46. Sadeghi, K., \& Khezrlou, S. (2016). The experience of burnout among English language teachers in Iran: Self and other determinants. Teacher Development, 20(5), 1-17.

47. Sadeghi, K., Khezrlou, S., \& Modirkhameneh, S. (2017). CALLing Iranian learners of L2 English: Effect of gloss type on lexical retention and academic reading performance under different learning conditions. Journal of Research in Reading, 40(1), 66-86.

48. Segalowitz, N. (2010). Cognitive bases of second language fluency. Abingdon: Routledge.

49. Sydorenko, T., Smits, T. F. H., Evanini, K., \& Ramanarayanan, V. (2019). Stimulated speaking environments for language learning: Insights from three cases. Computer Assisted Language Learning, 32, 17-48.

50. Slavich, G. M., \& Zimbardo, P. G. (2012). Transformational teaching: Theoretical underpinnings, basic principles, and core methods. Educational Psychology Review, 24(4), 569-608.

51. Thornbury, S. (2005). How to teach speaking. Essex: Pearson Longman.

52. Zajonc, A. (2008). Mediation as contemplative inquiry: When knowing becomes love. West Stockbridge: Lindisfarne Press.

\section{Appendix}

\section{Appendix A}

\section{Contemplative Approach Questionnaire}

Direction: Please answer the following items by circling the letter of the alternative which appears most applicable to you.

$\mathbf{1}$ = strongly disagree $\mathbf{2}$ = disagree $\mathbf{3}$ = neither disagree nor agree $\mathbf{4}$ = agree $\mathbf{5}$ = strongly agree 
1. Studying English with contemplative approach is an enjoyable experience.

2. I would rather spend my time on an approach other than contemplative.

3. I think that learning English with the contemplative approach is dull.

4. Studying English in the contemplative approach can be important for me because I will be able to participate more freely in the activities of English groups.

5. The more I know about the contemplative approach, the more I like them.

6. Studying English in the contemplative approach is important to me because it will enable me to get to know various cultures and peoples.

7. I would like to know more about contemplative approach.

8. Studying English in the contemplative approach can be important for me because it will make me a more knowledgeable person.

9. Studying English in the contemplative approach often gives me a feeling of success.

10. Studying English in the contemplative approach often makes me feel satisfied.

11. Studying English in the contemplative approach provides an interesting intellectual activity for me.

12. Studying English in the contemplative approach is important to me because it offers a new challenge in my life, which has otherwise become a bit monotonous.

13. Contemplative approach adds a distinctive flavor to the English language culture.

14. I have a favorable attitude towards the contemplative approach.

15. Studying English in the contemplative approach can be important for me because it will make me a more knowledgeable person.

16. In classes following contemplative approach, it embarrasses me to volunteer answers.

17. I never feel quite sure of myself when I am speaking in our class following contemplative approach.

18. I get nervous and confused when I am speaking in my class following contemplative approach.

19. I am afraid the other students will laugh at me when I speak in my class following contemplative approach.

20. Studying English in the contemplative approach can help me speak with foreigners easily. $\begin{array}{lllll}1 & 2 & 3 & 4 & 5\end{array}$

$\begin{array}{lllll}1 & 2 & 3 & 4 & 5\end{array}$

$\begin{array}{lllll}1 & 2 & 3 & 4 & 5\end{array}$

$\begin{array}{lllll}1 & 2 & 3 & 4 & 5\end{array}$

$\begin{array}{lllll}1 & 2 & 3 & 4 & 5\end{array}$

$\begin{array}{lllll}1 & 2 & 3 & 4 & 5\end{array}$ $\begin{array}{lllll}1 & 2 & 3 & 4 & 5\end{array}$

$\begin{array}{lllll}1 & 2 & 3 & 4 & 5\end{array}$

$\begin{array}{lllll}1 & 2 & 3 & 4 & 5\end{array}$ $\begin{array}{lllll}1 & 2 & 3 & 4 & 5\end{array}$ $\begin{array}{lllll}1 & 2 & 3 & 4 & 5\end{array}$ $\begin{array}{lllll}1 & 2 & 3 & 4 & 5\end{array}$ $\begin{array}{lllll}1 & 2 & 3 & 4 & 5\end{array}$ $\begin{array}{lllll}1 & 2 & 3 & 4 & 5\end{array}$ $\begin{array}{lllll}1 & 2 & 3 & 4 & 5\end{array}$ $\begin{array}{lllll}1 & 2 & 3 & 4 & 5\end{array}$ $\begin{array}{lllll}1 & 2 & 3 & 4 & 5\end{array}$ $\begin{array}{lllll}1 & 2 & 3 & 4 & 5\end{array}$

$\begin{array}{lllll}1 & 2 & 3 & 4 & 5\end{array}$ $\begin{array}{lllll}1 & 2 & 3 & 4 & 5\end{array}$ 


\section{Appendix B}

\section{Transformative Approach Questionnaire}

Direction: Please answer the following items by circling the letter of the alternative which appears most applicable to you.

$\mathbf{1}$ = strongly disagree $\mathbf{2}$ = disagree $\mathbf{3}$ = neither disagree nor agree $\mathbf{4}$ = agree $\mathbf{5}$ = strongly agree 
1. Studying English with transformative approach is an enjoyable experience. $\quad \begin{array}{lllll}\mathbf{1} & \mathbf{2} & \mathbf{3} & \mathbf{4} & \mathbf{5}\end{array}$

2. I would rather spend my time on an approach other than transformative. $\quad \begin{array}{lllllll} & \mathbf{2} & \mathbf{3} & \mathbf{4} & \mathbf{5}\end{array}$

3. I think that learning English with the transformative approach is dull. $\quad \begin{array}{lllllll} & & \mathbf{1} & \mathbf{3} & \mathbf{4} & \mathbf{5}\end{array}$

4. Studying English in the transformative approach can be important for me $\quad \begin{array}{lllll}\mathbf{1} & \mathbf{2} & \mathbf{3} & \mathbf{4} & \mathbf{5}\end{array}$ because I will be able to participate more freely in the activities of English groups.

5. The more I know about the transformative approach, the more I like them.

6. Studying English in the transformative approach is important to me because it will enable me to get to know various cultures and peoples.

7. I would like to know more about transformative approach.

$\begin{array}{lllll}1 & 2 & 3 & 4 & 5\end{array}$

8. Studying English in the transformative approach can be important for me because it will make me a more knowledgeable person.

$\begin{array}{lllll}1 & 2 & 3 & 4 & 5\end{array}$

9. Studying English in the transformative approach often gives me a feeling of $\begin{array}{lllll}\mathbf{1} & \mathbf{2} & \mathbf{3} & \mathbf{4} & \mathbf{5}\end{array}$ success.

10. Studying English in the transformative approach often makes me feel satisfied.

11. Studying English in the transformative approach provides an interesting intellectual activity for me.

12. Studying English in the transformative approach is important to me because it offers a new challenge in my life, which has otherwise become a bit monotonous.

13. Transformative approach adds a distinctive flavor to the English language $\quad \begin{array}{rllll}\mathbf{1} & \mathbf{2} & \mathbf{3} & \mathbf{4} & \mathbf{5}\end{array}$ culture.

14. I have a favorable attitude towards the transformative approach.

$\begin{array}{lllll}1 & 2 & 3 & 4 & 5\end{array}$

15. Studying English in the transformative approach can be important for me because it will make me a more knowledgeable person.

16. In classes following transformative approach, it embarrasses me to volunteer answers.

17. I never feel quite sure of myself when I am speaking in our class following transformative approach.

18. I get nervous and confused when I am speaking in my class following transformative approach.

19. I am afraid the other students will laugh at me when I speak in my class following transformative approach.

20. Studying English in the transformative approach can help me speak with foreigners easily.

$\begin{array}{lllll}1 & 2 & 3 & 4 & 5\end{array}$

$\begin{array}{lllll}1 & 2 & 3 & 4 & 5\end{array}$

$\begin{array}{lllll}1 & 2 & 3 & 4 & 5\end{array}$

$\begin{array}{lllll}1 & 2 & 3 & 4 & 5\end{array}$

$\begin{array}{lllll}1 & 2 & 3 & 4 & 5\end{array}$

$\begin{array}{lllll}1 & 2 & 3 & 4 & 5\end{array}$ 


\section{Motivated Strategies for Learning Questionnaire-MSLQ questionnaire}

1

not at all

true of me me

1. I ask myself questions to make sure I know the material I have been studying.

2. When work is hard I either give up or study only the easy parts.

3. I work on practice exercises and answer end of chapter questions even when I don't have to.

4. Even when study materials are dull and uninteresting, I keep working until I finish.

5. Before I begin studying I think about the things I will need to do to learn.

6. I often find that I have been reading for class but don't know what it is all about.

7. I find that when the teacher is talking I think of other things and don't really listen to what is being said.

8. When I'm reading I stop once in a while and go over what I have read.

9. 1 work hard to get a good grade even when I don't like a class.

\section{Figures}




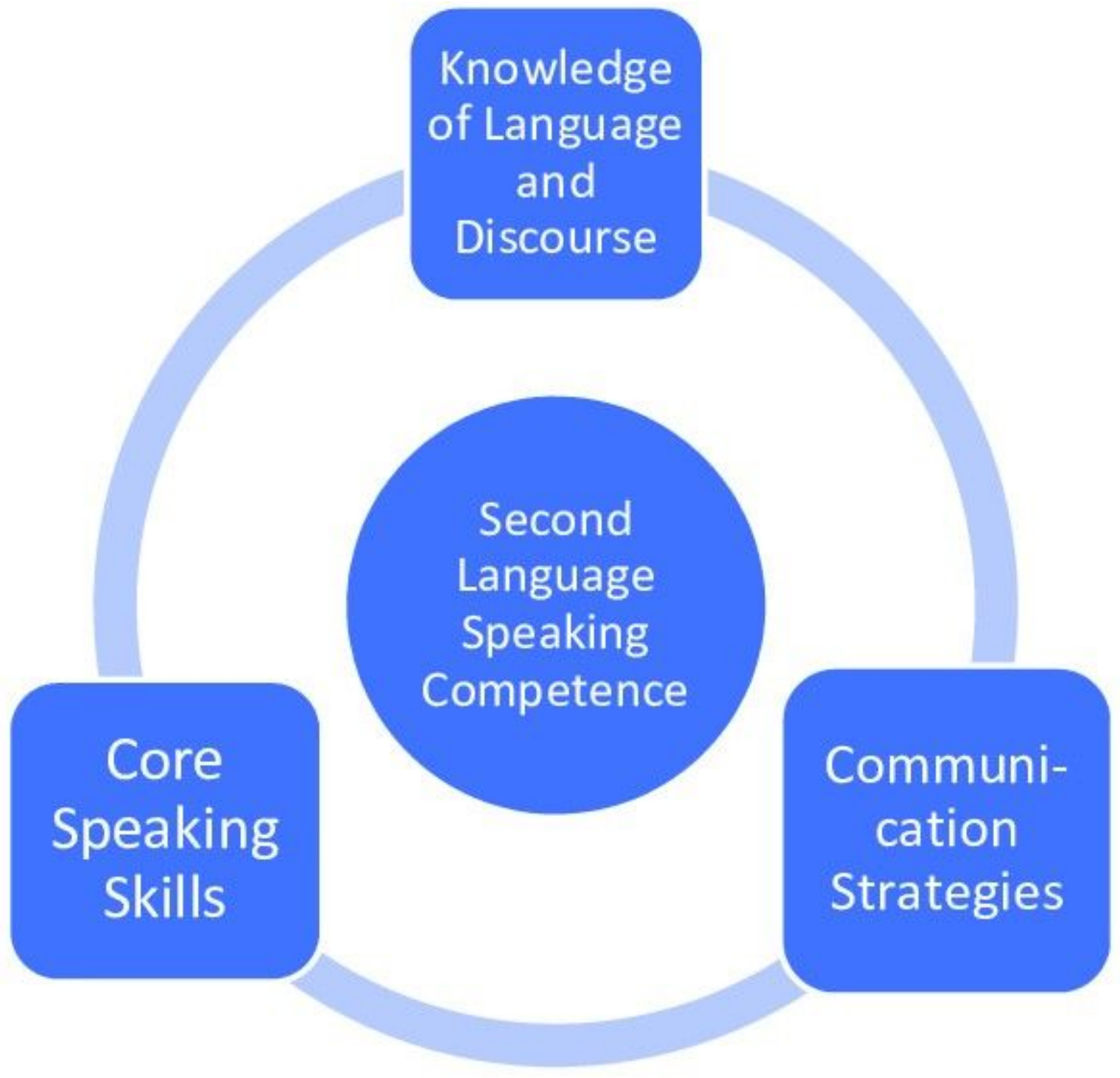

Figure 1

Components of second language speaking competence (Goh \& Burns, 2012, p. 53) 